\title{
Søren Kierkegaard: Fra martyr til menneske
}

Kierkegaard er i sit 200-års jubilæum blevet fejret af alle medier og alle steder i det københavnske byrum. Er den kontroversielle Kierkegaard gået hen og blevet mainstream som nationalklenodie og psykologisk sandhedssiger? I hvert fald fejrede det officielle Danmark Søren Kierkegaards 200-års fødselsdag d. 5. maj 2013 i Dronningens nærvær. Biskoppen afholdt sig dog klogeligt fra at prædike over fødselaren ved festgudstjenesten i Domkirken. Kierkegaard var linsen, ikke evangeliet. Og ved den efterfølgende fejring i Universitetets Festsal var det Kierkegaard som martyr, der blev tematiseret, efter at Søren Kierkegaard Forskningscentret forinden havde afleveret Niels Jørgen Cappelørns fornemme 55 binds udgave af Kierkegaards værker til eftertiden. Kierkegaard kræver passion, både af sine læsere og af sine udgivere!

Dansk Teologisk Tidskrift bringer festforelæsningen fra d. 5. maj som særnummerets første artikel. Minutiøst gennemgår Bruce Kirmmse de forskellige stadier i Kierkegaards diskussioner med sig selv, om geniet også var martyr eller blot en digter. Fornuftens tidsalder afkræver nemlig ikke blod af vidnerne som i passionens tidsalder, men kun deres latterliggørelse. Til sidst indser Kierkegaard dog med lettelse, at han blot er et menneske, der gestikuler i sin daglige eksistens. Mindre end en virkelig martyr, men dog noget mere end blot en digter!

De næste artikler sætter Kierkegaard i forhold til nutidens filosofi og videnskab. Pia Søltoft foretager en inciterende læsning af Kjerlighedens Gjerninger i lyset af nyere gaveteorier. Men for Kierkegaard er det ikke modtageren, der bliver sat i gæld, men derimod giveren, der får lov til at skænke. Gavens økonomi er af sin egen art, når det drejer sig om kærlighed. For kærligheden er ældre end alt, hverken giverens eller modtagerens ejendom. Kærlighedens gave er derfor ikke et bytteobjekt, og enhver gensidighed forudsætter kærligheden som tredjeparten. Margarete Dorothea Glöckner diskuterer tilsvarende Sygdommen til Døden i lyset af nyere sociolingvistik. I høfligheden er der forskel mellem det sagte og det mente. Men mens sociolingvister mest ser høfligheden som en strategi for at undgå sociale konflikter, kan Kierkegaards indirekte meddelelse læses som en hensyntagen til den krænkede modpart, der får plads til selv at tænke med og handle videre. Høfligheden åbner mulighedens dimension for alle involverede. Der etableres en gensidighed uden gengældelse. Til sidst genovervejer René Rosfort Kierkegaards kritik af naturvidenskaberne. Han viser, at Kierkegaards angreb på videnskaben efter 1846 mest angår den spekulative naturvidenskab i samtidens romantik. Den empiriske naturvidenskab er relativt ufarlig, om end eksistentielt uvedkommende. For afgørende er det ikke kun, hvad et menneske er, men hvem et menneske er. 